\title{
Endangered Settlements and Protected Areas in Estonia - The Challenge of Maintaining Cultural Landscapes
}

\begin{abstract}
:
This article discusses the conservation of protected areas of Estonia and rural cultural landscapes, in order to provide baseline information for key institutions in protected areas to develop more efficient management policies for cultural landscapes. Based on demographic and settlement analysis of protected areas, we found that present conservation management practices in limited management zones do not guarantee the sustainability of cultural landscapes, as human activity there is practically vanishing. We found that ensuring sustainable human activity, which is the key factor to preservation of cultural landscapes, benefits from the reduction of legal and practical restrictions on human activity in limited management zones. We propose a methodology which can be used to assess the viability of settlements located in protected areas and select endangered settlements ( $20 \%$ of settlements located in protected areas), where relieving restrictions of nature conservation would be beneficial. Additionally we propose four possible policies for reducing such restrictions.
\end{abstract}

Keywords:

Protected area management, nature conservation, cultural landscapes, natural and cultural heritage, rural development, rural depopulation, settlement viability, community development.

\section{Addresses:}

\section{Jaak Kliimask}

Lecturer,

Department of Landscape Management and Nature Conservation,

Institute of Agricultural and Environmental Sciences,

Estonian University of Life Sciences

Kreutzwaldi 5, 51014

Tartu, Estonia

jaakk65@hot.ee

Priit-Kalev Parts*

Lecturer,

Programme Manager,

Department of Estonian Native Crafts,

University of Tartu, Viljandi Culture Academy

Posti 1, 71004 Viljandi, Estonia

priit.kalev.parts@ut.ee

*Corresponding author 


\section{Henri Järv}

Technican,

Department of Landscape Management and Nature Conservation, Institute of Agricultural and Environmental Sciences,

Estonian University of Life Sciences

Kreutzwaldi 5, 51014 Tartu, Estonia

henri.jarv@emu.ee

\section{Kalev Sepp}

Head of Department, Professor, Department of Landscape Management and Nature Conservation, Institute of Agricultural and Environmental Sciences, Estonian University of Life Sciences

Kreutzwaldi 5, 51014 Tartu, Estonia

Kalev.Sepp@emu.ee

\section{Raymond Ward}

Senior Lecturer,

Aquatic Research Centre, University of Brighton, UK;

Department of Landscape Management and Nature Conservation, Institute of Agricultural and Environmental Sciences,

Estonian University of Life Sciences

Kreutzwaldi 5, 51014 Tartu

R.D.Ward@brighton.ac.uk

\section{Biographical notes:}

Jaak Kliimask (Msc, Human Geography) is lecturer at Estonian University of Life Sciences. He reads courses on rural geography and regional development.

Priit-Kalev Parts graduated from the University of Tartu in 1997 in Estonian literature. During 1998-2003, he studied landscape architecture at the Estonian Agricultural University, earning the degree of Master of Science in natural sciences in 2003. In the same year, he enrolled in the $\mathrm{PhD}$ programme of the Institute of Agricultural and Environmental Sciences of the Estonian University of Life Sciences. Since 2005, he has held a lectureship at the Department of Estonian Native Crafts of the 
Endangered Settlements and Protected Areas in Estonia - The Challenge of Maintaining Cultural Landscapes

University of Tartu Viljandi Culture Academy and is the head of the Estonian Native Construction programme.

Henri Järv earned the degree of Master of Science in Landscape Protection and Preservation in the Estonian University of Life Sciences. Since then, he has been working as a technician at the Estonian University of Life Sciences and mainly been engaged in carrying out different domestic and international applied projects. In 2013, he enrolled in the $\mathrm{PhD}$ programme, his research being focused on the socio-economic effects of the protected areas.

Kalev Sepp is a Professor of Landscape Management and Nature Conservation at the Estonian University of Life Sciences (EMU). He reads courses on nature conservation, landscape ecology and management. He is the head of studies in environmental science at the Estonian University of Life Sciences, head of the Scientific Council of the Institute of Agricultural and Environmental Sciences. He was a Vice-President an elected Councillor (2004-2012) of the International Union for Nature Conservation (IUCN) and a Vice-Chair of the Scientific Commission on Ecosystem Management (IUCN CEM). His research and publications focus on evaluating the human impact to agricultural landscapes, landscape functions, methodological approaches for landscape and biodiversity monitoring, applying the concept of ecological networks in spatial planning.

Raymond Ward obtained his PhD from the University of Brighton where he is now currently a senior lecturer in physical geography. He is also a senior researcher at the Estonian University of Life Sciences. 


\section{Introduction}

This article encourages discussion concerning the value of protected areas and of rural cultural landscapes in global context of rural depopulation, with the aim of helping the international community of landscape researchers, managers of protected areas and decision-makers to develop more efficient and conscious policies to manage cultural landscapes in protected areas and to set priorities regarding conservation management and the allocation of resources. Relatively well-preserved cultural landscapes can still be found in Estonia (Figure 1). Such landscapes are important to the Estonian national identity and are highly valued both by the public as well as in national development plans and regulations (Estonian Ministry of Culture, 2006; Nature Conservation Act, 2004). At the same time, as a whole, the population situation in Estonia's rural areas shows signs of peripheralisation and a clear centre-periphery pattern has been established: the farther an area is from the cities, the more rapid the population decline (Kliimask et al., 2014). Obviously, the demographic trends in general and respective problems related to protected areas and regional development rather resemble those of Estonia both on European level (see Mose 2007) and globally (see Joppa 2012).

It is obvious that the decline in rural populations, and agriculture becoming more centred on large-scale production are processes that cannot be prevented, at least not in coming decades. The preservation of cultural landscapes and related natural assets worthy of conservation is not conceivable without permanent settlement. Estonian nature reserves typically protect semi-natural areas. Thus, a question that has become relevant in recent years among nature conservation professionals and people living in protected areas is whether people pursuing their traditional means of livelihood should be considered the key species in protected communities (Parts, 2007).

Presently, in the situation of post-productivistic countryside ${ }^{1}$, nature conservation itself has become a factor in countryside policy, and in protected areas it is one of the main factors directing land use (Tomson, 2007). Contemporary principles of regional development and regional politics both in Estonia (Estonian Ministry of the Interior, 2014) and in most Western countries (OECD, 2011; Stöhr, 1990) focus on local special characteristics to identify economic stimulus to reinvigorate peripheral areas, by directing the efforts towards rethinking skills, phenomena or places, and existing cultural elements and start implementing them as a new resource (Perkins 2006, p. 247; Gray, 2000). This also implies that since small-scale nature and culture tourism is a growing field (Saarinen, 2007), it is areas that preserve such values that have a strong competitive advantage as in addition to engaging in other fields, such as small-scale and organic farming, they also boast picturesque natural and cultural assets.

The socio-economic and demographic indicators of protected areas in Estonia are significantly below the Estonian average. Nevertheless, they are fairly comparable to those of other similar rural areas, thereby making this article relevant to the discussion about the viability of rural life in a wider geographical context. For instance, as a 
geographic pattern, it is evident that regional development is dependent on a region's location in relation to (larger) towns (Kliimask et al., 2014). It seems that protective restrictions have not had a noticeable effect. Population ageing and decline related to peripheralisation, a sharp decline in agriculture (previously a major factor in the rural economy) and other processes have undoubtedly been the primary drivers of this decline, although there have also been instances where the economic competitiveness of protected areas has fallen even faster due to restrictions (Kliimask et al., 2014).

In relation to this, nature conservation policy has been given unprecedented responsibility in fields in which it has not been traditionally engaged (cf. Mose, 2007). As historical cultural landscapes can only be preserved to a limited extent and presumably it is in the protected areas where the culturally more valuable rural landscapes are situated. The authors conclude that it is precisely for the preservation of landscapes in protected areas that nature conservation policy has to get more forcefully involved with the issues of regional development and settlement policy than it has done so far. The research question of this article is how to ensure the preservation of traditional rural landscapes in conditions of general urbanisation, at least in the limited management zones of Estonian protected areas. This article analyses the potential of Estonian protected areas in the management of valuable natural assets found in cultural landscapes. Based on in-depth interviews, new potential policies for streamlining the management of cultural landscapes are proposed. Analysing and planning the protection regime of cultural landscapes located in protected areas is also relevant since in relation to peripheralisation, some cultural landscapes located in protected areas lose valuable assets that have so far been subject to protection pursuant to protection rules. The results of the survey conducted in Lahemaa National Park highlighted several problems: for large-scale producers, the land in Lahemaa is not sufficiently fertile and has complicated ownership and administrative issues; for local small-scale producers and cattle farmers it is difficult to build suitable production buildings due to architectural rules and volume constraints (EMÜ report, 2014; about architectural restrictions see Hiob et al., 2012; Kõivupuu et al., 2010). These restrictions make business economically unattractive or unprofitable in today's tough competition in the field of agriculture. Therefore, it is important to ask to which extent protection management practice, or in other words restriction of economic activity in limited management zones, is justified, even speaking in purely conceptual terms, as we find ourselves in a situation where the pressure from economic activities that would require regulation has practically ended or is already nonexistent.

Settlement trends can be affected by implementing active and passive measures. Active measures help reinforce rural life by different types of support (e.g. various subsidies, infrastructure development etc.); passive measures increase the viability and economic competitiveness of the area by relieving certain restrictions (e.g. by avoiding a situation where it would be cheaper and easier to live or engage in agriculture or forestry 
elsewhere, etc.). Several aspects have to be considered when developing appropriate solutions and finding balance between the needs of the protection regime and socioeconomic development. This article focuses on connections between restrictions in protected areas and regional development as these connections constitute one of the key issues of protected area and regional development. We try to outline the general features of the methodology which could be used as a basis for changing the content or territorial pattern of restrictions in protected areas. We focused more closely on Lahemaa National Park (LNP), the largest and oldest national park in Estonia, by conducting structured interviews and on-site observations.

\section{Methods and data gathering}

There are more than 4,621 rural settlements in Estonia; out of these 269 settlements are located in protected areas (Census 2011, Statistics Estonia, www.stat.ee). Since the demographic situation of protected areas in Estonia is different in individual settlements, there are a large number of settlements and the measures applied in practice are probably relatively location- and case-sensitive, there is a practical need to narrow down the sample and selection of settlements whose protection regime and "settlement policy" (relief of restrictions, other measures) will be focused on.

In order to predict demographic processes, we studied rural settlements between 20002011, analysing the features of the settlements that grew or diminished and how rapidly this occurred. We proceeded from the following assumptions:

1) permanent settlement is a precondition for preserving cultural landscapes;

2) the selected features based on which settlements were analysed (population age structure, demographic dynamics, and housing) are sufficiently characteristic;

3) effects of external environment remain stable for ten years or more;

4) population trends in rural areas by settlement types are in principle no different in protected areas than anywhere else (Kliimask et al., 2014).

In order to manage cultural landscapes located in protected areas and to design appropriate protective measures in areas with decreasing rural populations, it is essential to understand the viability of settlements situated in the limited management zones of protected areas. This study has identified less viable settlements from the total settlements in the limited management zones in order to select endangered settlement areas (i.e. those which are, or are in danger of becoming, empty).

In order to identify endangered settlement areas, we used statistical indicators related to the survival of settlements. We mostly concentrated on analysing demographic change and structure indicators, and housing, in order to distinguish settlements that are problematic from the point of view of settlement sustainability in synchronic perspective and settlements which, in the light of current trends, are likely to become problematic in 
Endangered Settlements and Protected Areas in Estonia - The Challenge of Maintaining

Cultural Landscapes

the future. However, since forecasts concerning such small-sized territorial units raise some technical and methodological doubts, it was considered more appropriate to treat the selected problematic settlements as potentially problematic due to the age structure of the population.

We received our data from the censuses of 2000 and 2011, and we selected villages and hamlets to be our basic units. The first criterion we selected for distinguishing less viable settlements was their size, in combination with either population age structure or demographic dynamics indicators. We made a distinction between the following groups of endangered settlements:

1. Very small hamlets (very sparsely populated) where a single life change might result in the hamlet becoming totally empty or which are so sparsely populated that the term "settlement" cannot be applied to them any longer;

2. Settlements with (mainly) an elderly population whose economic activity is low, also from the perspective of potential landscape maintenance; as a result of the old age of population, the settlement will potentially disappear in the long-term;

3. Settlements that have rapidly emptied in the past decade and where no new residential buildings have been built in this period; they have been unattractive as residential areas.

Considering villages and hamlets to be more or less viable cannot be taken as the basis for automatic relief or removal of any restrictions in protected areas or for implementing any other measures. Protected areas in Estonia have different aims and their socioeconomic situation varies greatly. In order to assess whether the methodology proposed for technical selection of viable settlement is practically applicable, fieldwork was carried out in April 2014 in Lahemaa National Park (LNP), the largest and oldest national park in Estonia (hereinafter referred to as EMÜ report 2014).

A structured questionnaire was designed to obtain both quantitative and qualitative data. The interviews were scheduled to take place before active tourism and the agricultural season (April 2014) so that the locals could allocate time for us (the length of interviews varied between 90 minutes and 2 hours. We adapted the snowball method that had also been used in earlier projects (see Palang et al., 2011; Reimann et al., 2011). We first contacted persons within Lahemaa based on our earlier studies and asked them to recommend further informants. However, we specified that our interest was collecting input from direct sources to attain insights into the local community's and stakeholders' attitudes towards, and relationship with, the regulations and protection practices, as this would support and inspire the development of management practices of cultural landscapes that could be implemented in practical nature conservation, and the assessment of viability of settlements located in protected areas. Therefore, in preparing our sample, we preferred representatives directly connected to functioning and preservation of cultural landscapes. Altogether, 32 people were interviewed. 
Interviewees provided further contacts and were in direct contact with future interviewees on behalf of the study group in advance of the interview. Our interviews therefore took place in a relaxed atmosphere. The length of the interview placed a big responsibility on the interviewer regarding preparation, since such a long interview is straining for the interviewee and it would not be possible to visit the same people again in the near future. Represented stakeholders included permanent local residents, either workers or entrepreneurs, from different fields of life (forestry, tourism, agriculture, fishing, hunting), officials from the Environmental Board and local municipalities, specialists from the State Forest Management Centre, and land owners. Questions focused on aspects such as relations between the LNP's current regulations and administrative practices, and the effects on economic activities and living, first and foremost on forestry and agriculture, building restrictions and real estate development, business and migration. The questions also touched upon local residents' assessment and interpretations of protection management measures currently in force (subsidies, restrictions, availability and quality of administrative and support services).

\section{Management and socio-economic development of protected areas in Estonia: current situation and prospects}

Estonian national parks and other protected areas have local residents within their boundaries; ca $23 \%$ of protected areas are on private land. This is in direct contrast to other countries within the Baltic region (the Baltic states and those of Fennoscandia). A total of $18.1 \%$ of Estonia's surface area (including inland waters, apart from the two largest lakes (Lake Võrtsjärv and Lake Peipus) and 31.1\% of Estonian waters are under protection. A total of $22.7 \%$ of Estonian surface area (land and water area combined) is under some form of nature protection. This includes 932 protected areas: 5 national parks, 131 nature reserves, 150 landscape reserves and nature parks, 107 protected areas with unrevised protection rules, and 539 protected parks and stands (EEIC, 2012).

The Republic of Estonia Nature Protection Act [Looduskaitseseadus] (adopted in 2004) states that each protected area should have approved protection rules and a management plan. The protection regime for protected areas is determined by the protection rules. Within the legal context, the protection rules provide an additional level of detail to the specifications of the Nature Conservation Act (2004).

Estonian national parks and nature reserves are divided into one or several strict nature reserves, conservation zones and limited management zones. In the case of protected landscapes, only conservation zones and limited management zones are designated (for further details see Kliimask et al., 2014). When assessing the situation of settlements and the viability of communities as preconditions for preservation of cultural landscapes, it is important to focus on limited management zones $^{2}$ as these are where most forestry-, agricultural and construction activities occur. The primary protection aim of limited 


\section{Endangered Settlements and Protected Areas in Estonia - The Challenge of Maintaining Cultural Landscapes}

management zones is preservation, recovery, study and introduction of natural and cultural heritage, encompassing landscape appearance, topography, protected species and their habitats, natural and cultural landscapes, agricultural land use, settlement structure, farm architecture, and folk culture characteristic of the region. It should be noted here that in Estonia, a traditional cultural landscape is considered to be an area where the land use had developed by the year 1940 and where the historical land cover and/or use has been preserved.

Many of these nature conservation areas are important in terms of biodiversity as well as due to the presence of regionally rare or important species particularly within seminatural communities. To restore and maintain these semi-natural communities, both European Union and state subsidies can be employed. A further stimulus to nature conservation is that pursuant to the Land Tax Act, land in strict nature reserves and conservation zones of protected areas as well as in conservation zones of species protection sites became exempt from land tax as of 1 January 2009.

The development of protected areas has been affected both directly and indirectly by many interrelated social, economic and demographic factors ${ }^{3}$. Changes have been rapid and extensive and many processes are likely to continue in the near future. The results of a population census of protected areas have shown that population decline in Estonia's protected areas is significantly greater than the Estonian average. In the last decade the population of Estonia has decreased by an annual average of $-0.47 \%$, whilst in protected areas, the population has decreased by $-1.2 \%$ over the same period. The few that move into protected areas are typically middle-aged and middle class. However, most inhabitants of protected areas are disadvantaged compared to other similar rural areas, which has led to an exodus of people in search of work in other areas. An important exception to this are the inhabitants of the LNP who are, on average, less disadvantaged than inhabitants of similar rural areas. This is, however, most likely as a result of its location in the vicinity of, and accessibility from, Tallinn (Kliimask et al., 2014).

The LNP, the focus of interviews in the current paper, is both exceptional and representative as an Estonian protected area in many senses. It is the oldest national park (founded 1971) in the territory of the former Soviet Union. The LNP is also the largest national park in Estonia by its surface area (47,400 ha in mainland, 3,598 residents). There are a total of 70 settlements in the territory of the protected area, the largest of which are small towns of Kolga (population 454) and Võsu (population 334); there are 61 hamlets with less than 100 residents. The national park is located in the territory of two rural municipalities, Kuusalu and Vihula, the first of which reaches the commuterbelt of Tallinn, the second, however, is more remote from larger settlements. Rural municipalities are sparsely populated (population density in Vihula under 4 people $/ \mathrm{km}^{2}$ ) and are of Estonian average wealth. 
Officially, the LNP was created to protect characteristic North-Estonian landscapes and the national heritage of the area, and to preserve the harmonious relationship between man and nature. But the initiative also carried a hidden agenda of the patriotically disposed Soviet Estonian political and economic establishment. The agenda was to create a cultural and natural buffer zone between the rapidly developed and sovietised industrial areas in Tallinn and North-East Estonia (Printsmann et al., 2011; Smurr, 2008). However, following the regaining of independence in Estonia (1991) ecological values of the LNP also became important and the LNP started to harmonize its legislation with EU.

As a whole, the population situation in Estonia's rural areas, including protected areas, carries the signs of peripheralisation and a clear centre-periphery pattern has been established: the greater the distance of an area is from the cities, the more rapid the population decline (Kliimask et al., 2014). If we compare the population dynamics of protected areas with other rural areas located in similar geographic locations, we typically find no significant differences. This was as relevant during the Soviet period in Estonia as in the last decade. However, location related differences in population dynamics are significant and these differences have polarized considerably over time, and the centre-periphery pattern and peripheralisation processes have deepened as a whole (Sepp E., 2011; Roose et al., 2010).

\section{Demographic and settlement analysis of protected areas in Estonia}

In the course of our initial general analysis of the demographic situation of protected areas in Estonia, a demographic paradox emerged: for settlements with a higher mean age, a more stable demographic situation was predicted for the forthcoming decade (especially in rural settlements where the proportion of 40-70-year old people dominated). The opposite was also true: settlements with a large proportion of people aged 40 and under showed that the population was rapidly declining and the process was accelerating. In other words, as the younger population is more mobile, demographic changes in settlements are largely determined by the proportion of young people as potential leavers.

As the development of cultural landscapes is a long-term process, the high proportion of elderly and pre-elderly in the population is worrying. It is clear that people become economically less active from the age of 60 for biological, socio-political and motivational reasons (many people reach retirement age or become eligible for early retirement). The potential conclusion that the youth of population as such is a source of risk is also unlikely to be true: it is possible that once external environmental conditions change, the population aged under 40 becomes more settled or even starts to encourage moderate immigration, not to mention the entrepreneurship and reproductivity conditioned by age. These results also need to be considered with utmost caution as the 


\section{Endangered Settlements and Protected Areas in Estonia - The Challenge of Maintaining}

Cultural Landscapes

analysis is conducted based on micro units (3,000-5,000 people) and making demographic predictions based on such data is highly questionable.

To distinguish settlements that are becoming empty, we set the critical limit at 5 inhabitants. Usually it is only elderly people or a single household that live in such hamlets. Setting the limit at 5 people is also supported by statistical analysis: in the villages that had become empty by 2011, there were on the average 3.4 residents according to the 2000 census; also $73.3 \%$ of villages empty by 2011 had less than 5 residents in 2000 .

Of endangered settlements (see section Methods and data gathering), we excluded the following settlements as viable due to vigorous construction activity:

1) settlements where at least 5 new dwellings have been built in the past 10 years;

2) settlements with at least 10 dwellings - these are summer holiday regions. There were two such settlements in the LNP, the villages of Natturi with 15 and Lauli with 13 residential buildings;

3) settlements located in the commuting zone of larger towns - about one third of the residents commute to a larger town in a $30 \mathrm{~km}$ zone ${ }^{4}$.

In order to create the background of the situation, the division of main demographic indicators of protected areas and all rural settlements in Estonia is presented in Table 1. The number of very small settlements with less than 5 inhabitants is low in Estonia, less than $10 \%$; the number is somewhat larger in protected areas, as these settlements tend to be more remote from larger centres and in areas which are more sparsely populated than the average. In the period 2000-2011, approximately $40 \%$ of settlements experienced an average annual population decline over $2 \%$; in this respect, protected areas are relatively similar to Estonian rural settlements in general. Larger settlements are also diminishing rapidly; this is part of the general population decline in Estonia which has been relatively massive and rapid in the past decades. The proportion of people aged 65 and older is relatively comparable although not overlapping with the proportion of small settlements: under $10 \%$ in Estonia in general and approximately 15\% in protected areas. Since population decline has been a long-term process in rural areas, there are also many empty living rooms : settlements with at least 10 empty living rooms in Estonia make up almost a quarter of all settlements; in protected areas, almost one third. This means that in many small hamlets, there is a remarkably large number of single person households; there are also many old farm buildings without permanent inhabitants being used as summer cottages. This constant population decline also means that not many new residential buildings are constructed in rural areas: in approximately $90 \%$ of rural settlements, less than 5 new living rooms have been built in the past decade. The proportion of such settlements in protected areas is somewhat lower, $80 \%$, as they are situated in naturally beautiful places and are therefore more attractive places for building summer cottages. 
By combining the aforementioned demographic indicators - small population size, age structure and demographic dynamics - we can develop different indicators that characterise the sustainability and viability of settlements. In this article, our main methodological focus is on distinguishing very weak and unviable settlements. Table 2, 3 and Figure 2 show the potential number, proportion and location of such settlements by applying different principles. This might be an important argument when implementing the methodology in practice, as desirably the proportion of problematic areas should be as small as possible, so that it would not dramatically alter established policies for protected areas in Estonia.

Based on the assumption that the problematic aspect (danger of becoming extinct) to a settlement is expressed simultaneously by size, overly large proportion of the elderly and overly rapid population decline, there are 20 such settlements out of 269 , i.e. $7.4 \%$ in protected areas in Estonia. There has been no building activity in these settlements in the past decades and the total number of living rooms is also small. The total proportion of such settlements in Estonia as a whole is $4.5 \%$; therefore the problem is significantly more serious for protected settlements.

If we extend the endangered state of a settlement so that a settlement is considered to be in danger of becoming rapidly empty when the number of inhabitants is below 5, or if in a settlement with less than 7 inhabitants the proportion of people aged 65 or older is more than $50 \%$, or in a settlement with less than 7 inhabitants the average annual population decline in the past decade is at least $-2 \%$ or more, then the number of such settlements in Estonia is more than twice as large: $17.8 \%$ in protected areas and $11.1 \%$ in Estonia in general. Some settlements can be excluded from the list based on the number of houses and intensity of the construction of new living rooms. In protected areas, this is true for two settlements (Natturi and Lauli) which are both established summer holiday areas where settlement is not in danger and restrictions could be left in force. The proportion of settlements serving as summer holiday areas in Estonia in general is approximately the same. By keeping in mind the problem of disappearing rural settlement as a whole and based on the aforementioned calculations, we recommend relieving protective restrictions in about one fifth of the settlements located in protected areas (in 46 settlements, i.e. $17 \%$ ).

\section{Review of stakeholders' attitudes towards protection regime and practices in the example of Lahemaa National Park}

In order to find out stakeholders' attitudes, we conducted structured interviews in LNP. The following is an overview of the main findings of the survey.

In general, as the LNP has existed for such a long time (founded in 1971), the lifestyle of local residents has become adjusted to it. Residents of the LNP enjoy living there; their social circle considers it to be a place worth living and it is subjectively estimated that the 


\section{Endangered Settlements and Protected Areas in Estonia - The Challenge of Maintaining}

Cultural Landscapes

status of protected area also increases the value of real estate (buildings, land under buildings). It was found that the value of profit yielding land (agricultural land, forest), on the other hand, decreases due to its location in the protected area ${ }^{5}$.

Local residents of the LNP do not generally question the necessity of the national park; however, they often do not understand what exactly is being protected and for what reason. The aims of protection and conservation zones are clearly defined in official documents; however, in protection practice and in the nature, boundaries are not so clear. Many decisions that affect local residents' freedom of action and opportunities are subjective and depend on the official making the decision. $60 \%$ of respondents found that the protection regime did not take the interests of permanent residents into sufficient consideration; only $12.5 \%$ of respondents found that the interests of permanent residents are sufficiently taken into account.

The most serious problems are considered to be peripheralisation and social problems. At the same time, respondents do not favour rapid growth (by founding new tourist objects, new business, or increased number of visitors) nor foreign immigration and the extensive construction of summer cottages. However, moderate growth at a medium pace was considered to be positive.

Regarding the landscape, the most annoying factor is considered to be "poor health" of forests (Figure 3), but also overgrowth of agricultural land and littering (allegedly by visitors and holidaymakers). What the respondents valued the most and considered worthy of protection in the LNP were the primeval forests, more specifically "forest milieu"; people would like to see "beautiful", traditionally coppiced forests (Figure 4). Respondents do not have a lot of contact with protected species and individual objects and therefore do not worry about these.

Residents of the LNP had a clearly negative attitude towards restrictions related to real estate, land use and logging; other restrictions are not directly felt (except for a few single instances concerning fishing). Whereas the restrictions related to real estate and land use affected the residents' own activities and freedom of action, then restrictions related to logging were seen more in relation to the general unmaintained state of forests, not insufficient logging. Regarding nature conservation restrictions, $84 \%$ of respondents found that they were sufficient in scope and $16 \%$ had no opinion. General relief of protection restrictions was seen as irrelevant; what was considered to be important was a decrease in restrictions for permanent residents of protected areas and the provision of financial subsidies.

Among other things, we also studied the residents' willingness to maintain the landscapes of their home region; it was found that $100 \%$ of respondents would agree to do this. Half of them $(51 \%)$ are willing to do that if their costs would be covered or they would obtain a financial benefit from this work. 
At present, local inhabitants feel that they are forced to meet unreasonably and unfairly high expectations: on the one hand, they are "protected objects" and are expected to continue the traditional way of life; on the other hand however, performance of this activity of public interest is not sufficiently supported. Thus, 59.4\% of the respondents found that the present system of subsidies is not sufficient; $34.4 \%$ had no opinion and just $6.2 \%$ evaluated the present system of subsidies as sufficient. According to the respondents, the situation could be improved by specifically developed financial subsidies, some compensatory measures (road maintenance, social services etc.) and a consultation service to help them cope with the restrictions in the national park.

In spite of the restrictions and complications, the majority of respondents preferred the status of the protected area to be maintained. When asked about the possible abolishment of the protected area, $78 \%$ of respondents were negative, $9 \%$ saw it as positive and the rest remained neutral. Although the proportion of supporters of the protected area was large, the interviews also revealed the main reason why the residents would consider abolishing the protected area or remained indifferent towards it. For permanent residents, the LNP has always been the prime example of a traditional, well-maintained, aesthetical and beautiful cultural landscape (see Figure 5), which is also one of the protection aims of the LNP. People have been proud of it and therefore also made allowances in their lifestyle. In practice, however, the boundaries of protection aims and conservation zones have become blurred and the increasing amount of untended agricultural and forest areas no longer support the idea of landscape maintenance. Therefore, locals find no point to the protected area and feel disappointed in it (Figure 1). If the current situation continues, disappointment in the LNP will increase, which could result in significantly less efficient cooperation between the managers of the protected area and local residents.

\section{Possible Measures: Implications for Managers and Policy Makers}

It can be estimated on the basis of the survey that the attitude of the inhabitants of the LNP towards developing the national park is conservative, pragmatic and mostly supportive, which corresponds very well with the ideology of the national park and the need to protect cultural landscapes. Such attitudes favour developing long-term strategic plans, finding financial support for such plans and implementing strategic measures.

According to the need to support regional development without damaging the values in protected areas, we outline four strategic approaches to managing cultural landscapes in landscape conservation areas and national parks. In outlining these approaches, we have relied on the methodology and calculations presented above, according to which it would be appropriate to reduce restrictions in approximately one fifth of the settlements located in protected areas. We have also relied on the existing nationally defined institutional division of responsibilities (management of protected areas - Environmental Board, visitor management - State Forest Management Centre etc.), known development issues 
and the attitudes of inhabitants of Lahemaa region and our previous experience in communicating with operating managers of protected areas and stakeholders.

Policy 1. General relief of restrictions in existing limited management zones. The relief would mostly concern restrictions on constructing new residential buildings for non-seasonal residents and buildings for primary production (such as fishery, agriculture, forestry) and tourism, where these do not conflict with the protection and development aims of the protected area.

The advantage of this approach is its organizational simplicity and clarity: it is possible to utilise the previously defined zones, without carrying out time-consuming analyses of different protected areas and the location specificity of different protected areas and settlements situated there.

As a potential disadvantage, it has to be mentioned that this approach might not be sensitive enough towards individual protected areas and the socio-economic situation and individual characteristics related to demographic viability in individual settlements in such areas, thereby giving differing results in other locales.

Policy 2. Relief of restrictions in existing limited management zones by individual settlements. Restrictions are reduced in individual settlements which are selected based on their current and predicted viability. This is an improvement on Policy 1 which adds the aspect of territorial constraint. With Policy 2, the methodology of selecting endangered settlements proposed in this article (see section Demographic and settlement analysis of protected areas of Estonia) or any other methodology used to assess the viability of settlements can be applied in the most straightforward manner.

Policy 2 enables the specific characteristics of individual protected areas and settlements located there to be taken into greater consideration, thereby substantially directing local development. The greatest danger regarding the selection of settlements where restrictions are to be relieved is posed by areas with low populations and loss of cultural landscapes. Thus, there is nothing to lose by relieving restrictions, as the pressure from economic activity is weak in any case. Relative legal and administrational clarity is guaranteed by the fact that the boundaries of limited management zones and the settlements located there are already fixed.

A disadvantage of Policy 2 is its substantial (disputable value positions, the question of whether demographic forecasts for small units are valid etc.) and political vulnerability. Therefore, selection might not be possible to implement by administrative measures only, but a legal status with political instruments should be applied.

Policy 3. Active landscape patronage. Administrating and managing maintenance "from above" by concluding landscape management contracts and directing and intermediating subsidies according to plan (mowing, coppicing, thinning, creation and maintenance of recreational infrastructure, maintenance of traditional architecture etc.) 
and clearly in the favour of local population, e.g. by setting landscape maintenance obligation as the criterion for receiving building rights. The administration of protected areas assumes a greater social and political responsibility than it has done so far and approaches local municipalities by involving these more closely in the development and implementation of protection management and by considerably closer integration of nature conservation policy with municipal development plans, strategies and statutory plans.

This approach would allow for better mobilisation of local potential (permanent population and businesses) by giving them a chance to earn additional income and thereby guaranteeing the continuing attractiveness of the cultural landscapes. The survey we carried out in Lahemaa showed that respondents took a lively interest in contributing to landscape management.

Implementing this policy is difficult or impossible in places where viable permanent settlement /population has already completely or almost completely disappeared as there is no one left to involve. The managers of protected areas might also be worried about the quality control of services acquired in such manner. The policy is contrary to the ideology of open market economy and difficult to "sell" politically in Estonia as many people might be reminded of Soviet era collective farms. Bringing the management of protected areas closer to local municipalities and integrating them might also be complicated by the fact that nature conservation is generally considered to be the responsibility of the state, i.e. the central government (EMÜ report, 2014) and small and overburdened local municipalities are not interested in taking on additional tasks.

Policy 4. Act without acting. At first sight, it seems as if no action is taken; there are no changes implemented in regulations or administrative structure. However, in order to improve the use of cultural landscapes for protection purposes, a flexible case by case approach is applied by tacit agreement: concessions are made or a blind eye is turned regarding economic activity in limited management zones with endangered population. Intentional undermanning and underfunding of protected areas can also be applied as de facto "relief of restrictions".

Policy 4 can also be implemented by intentionally favouring selected activities, target groups or persons which are important from the perspective of preservation of cultural landscapes, especially concerning activities related to primary sector (e.g. no architectural restrictions are applied to the construction of housing for the purpose of sheep farming but such restrictions do apply to buildings for pig farming or tourism purposes).

The advantage of Policy 4 is the fact that it is easy and inexpensive to implement - there is no need to change anything, resources should only be directed to shaping public attitudes through daily work and dissemination of information and current landscape monitoring is continued. It could be clearly felt that Lahemaa residents, especially 


\section{Endangered Settlements and Protected Areas in Estonia - The Challenge of Maintaining}

Cultural Landscapes

resource owners and processers latently supported this policy and to an extent this is how things function: there were quite a few respondents claiming that there was always a way to get things done if needed (although it was said to be time and energy consuming) and that was strongly dependent on the attitude of the local or responsible official working for the protected area (EMÜ report, 2014).

The negative aspect to this policy is the organization becoming increasingly unsystematic and a general weakening of law-abiding attitudes, possible corruption and power abuse and associated problems.

\section{Conclusions and discussion}

This article encourages discussion of the value of protected areas and rural cultural landscapes in general, with the aim of helping the managers of protected areas to shape more efficient and conscious policies to manage cultural landscapes of protected areas and to set priorities regarding protection management and allocation of resources.

Based on demographic and settlement analysis of protected areas, we found that in the current socio-economic and demographic conditions, protection management practice does not guarantee the sustainability of cultural landscapes in limited management zones in Estonia's protected areas, as human activity is practically vanishing in these zones. This finding was also supported by our analysis of related material and protection management practices, and the fieldwork and survey conducted in Lahemaa National Park. We found that in order to guarantee permanent human settlement, which is the key factor to the preservation of cultural landscapes, and to preserve valuable rural landscapes at least partially, it would be useful to relieve legal and practical restrictions set on human activity in the limited management zones of protected areas.

Based on a demographic and settlement analysis of protected areas in Estonia, we proposed a methodology for narrowing down the sample of settlements for assessing settlement policies and where restrictions in limited management zones should be reduced. In designing the methodology the demographic age structure of settlements, cultural and environmental value of the built-up area, presumable settlement pressure and regional centres were taken into consideration, thus highlighting areas where it would be appropriate to reduce restrictions and where not. We found that protection restrictions could be relieved in approximately $20 \%$ of settlements situated in Estonia's protected areas, altogether 46 villages and hamlets.

In addition to a general demographic analysis of Estonian protected areas, we carried out a survey regarding protection regimes in Lahemaa National Park. Based on this, we proposed four potential polices for relieving restrictions:

1. General relief of restrictions in existing limited management zones. 
2. Relief of restrictions in existing limited management zones by individual settlements with endangered population.

3. Active landscape patronage which motivates local population and includes them in landscape management by top-down administration.

4. An "act without acting" where seemingly nothing is done but the actual enforcement of restrictions and supervision are silently reduced.

In practical protection management, location-specific circumstances and the political acceptability of measures will probably also have to be taken into consideration on a case-by-case basis. With additional resources, it would be advisable to have a more detailed selection model for settlements with endangered populations in limited management zones. The authors acknowledge that the foundation of the methodology that is proposed for selecting endangered and preferable settlements are subjective in nature and disputable from a different value position. There is need for further research along two avenues. The first is a question of the technical validity of the methodology. As the results were calculated using hamlets as principal territorial base units, their boundaries do not correspond to those of protected areas, e.g. different regimes of protection. This means there are still questions about the connection between the impact restrictions and settlement vitality. Therefore there a recalculation should be performed. Secondly, the indicators chosen for the methodology should be tested in depth in Estonia and in neighbouring countries in the region.

The aim of this article is to contribute to the discussion of sustainable management of cultural landscapes. We are pleased if we have been able to support key institutions and persons of protected areas in Estonia and more broadly within a global context to make more informed and efficient management decisions.

\section{Acknowledgements}

This work was supported by institutional research funding IUT21-1 of the Estonian Ministry of Education and Research. The authors also thank the anonymous referees and the editor of the IJ of Agricultural Resources, Governance and Ecology for useful comments on an earlier draft of the paper. 
Endangered Settlements and Protected Areas in Estonia - The Challenge of Maintaining

Cultural Landscapes

\section{References}

Estonian Ministry of Culture (2006) Maa-arhitektuur ja-maastik. Uurimine ja hoidmine. Valdkonna arengukava 2007-2010. [Rural architecture and rural landscape. Study and preservation. Development plan 2007-2010] [online] http://search.tb.ask.com/search/redirect.jhtml?action=pick\&ct=GD\&qs=\&searchfor=Maa -arhitektuur+ja+maa-

maastik\&cb=HJ\&pg=GGmain\&p2=\%5EHJ\%5Exdm073\%5EYYA\%5Eee\&n=780bd280 \&qid=74748fe3d38744c2bb99ac59a0827cf6\&ss=sub\&pn=1\&st=sb\&ptb=7C1D5B94C913-4597-A922-

84EF4F5BF93A\&tpr=\&si $=$ pconvFF\&redirect $=$ mPWsrdz9heamc8iHEhldEcftaaofXWot2 y1vBC96DDmoCWUBmbzYSWc3rqpWQcPZg\%2BgPGGaW\%2B65AfOnHld\%2FW3 RSdz5hrgOKEDAJUaJ8T9TU\%3D\&ord=2\& (Accessed 20 August 2014).

Estonian Ministry of the Interior (2014) Eesti regionaalarengu strateegia 2014-2020. [Regional Development Strategy of Estonia] [online]. https://www.siseministeerium.ee/public/Eesti_regionaalarengu_strateegia_2014-2020.pdf (Accessed 20 August 2014).

EEIC (2012) Estonian Nature Conservation in 2011, Estonian Environment Information Centre, Tallinn.

EMÜ report (2014) Estonian University of Life Sciences Report, Eesti kaitsealade sotsiaal-majanduslik analüüs (Socio-economic analysis of Estonian Protected Areas, in Estonian). Kliimask, J., Järv, H. and Sepp, K. (compiled). [Manuscript in possession of Institute of Agricultural and Environmental Sciences, Estonian University of Life Sciences].

Evans, N., Morris, C. and Winter, M. (2002) 'Conceptualizing agriculture: a critique of post-productivism as the new orthodoxy', Progress in Human Geography, Vol. 26, pp. 313-332.

Gray, J. (2000) 'The Common Agricultural Policy and the Re-Invention of the Rural in the European Community', Sociologia Ruralis, Vol. 40 No. 1, pp. 30-52.

Joppa, L. (2012) 'Population Change in and around Protected Areas' Journal of Ecological Anthropology, Vol. 15 No. 1. pp. 58-64.Hiob, M., Maiste, J., Hansar, L., Nutt, N. and Reimets, Ü. (2012) Lahemaa rahvuspargi kaitsekorralduskava alusuuring: Lahemaa rahvuspargi külade arhitektuuri ja asustusstruktuuri analü̈̈s. [Basic study of protection management plan: Analysis of architecture and settlement structure of villages in Lahemaa National Park] Tartu: Artes terrae [Manuscript in possession of Environmental Board].

Kliimask, J. et al (2014) 'Nature conservation in remote rural areas: a win-win situation?' Dünkel, F. and Herbst, M. (Eds.), Think Rural!, Springer Verlag, pp. 193-208. 
Kõivupuu, M., Printsmann, A. and Palang, H. (2010) 'From inventory to identity cultural built heritage management in the Lahemaa National Park, Estonia', in Bloemers, J.H.F. et al. (Eds.), The cultural landscape heritage paradox: Protection and development of the Dutch archaeological-historical landscape and its European dimension, University of Amsterdam Press, Amsterdam, pp. 115-131.

Looduskaitseseadus [Nature Protection Act] (2004), [online]. http://www.riigiteataja.ee/ert/act.jsp?id=12808270 [Amended through 1 July 2010, accessed 8 July 2010].

Mose, I. (Ed.), (2007) Protected Areas and Regional Development in Europe. Towards a New Model for the 21 st Century, Ashgate Publishing, Hampshire.

Novak, J. et al (2013) 'Application of mobile phone location data in mapping of commuting patterns and functional regionalization: a pilot study of Estonia', Journal of Maps, Vol. 9 No. 1, pp. 10-15.

OECD (2011) OECD 'Regional Outlook 2011. Building Resilient Regions for stronger economies', OECD Publishing. http://dx.doi.org/10.1787/9789264120983-en (Accessed 13 April 2015).

Phillips, M. (2005) 'Differential productions of rural gentrification: illustrations from North and South Norfolk', Geoforum, Vol. 36 No. 4, pp. 477-494.

Printsmann, A., Kõivupuu, M. and Palang, H. (2011) 'The dual character of landscape in the Lahemaa National Park, Estonia', in Zoran, R. et al (Eds.), Landscapes, identities and development, Ashgate Publishing, Farnham, Surrey, UK, pp. 51-66.

Perkins, H.C. (2006) 'Commodification: Re-resourcing rural areas', in Cloke, P. et al. (Eds.), Handbook of Rural Studies, Thousand Oaks, London; SAGE Publications, New Dehli, pp. 243-257.

Roose, A., Raagmaa, G. and Kliimask, J. (2010) 'Rural development trajectories in the Estonian periphery: impacts of the EU Cohesion Policies.' Paper Presented at the Annual International Conference of Regional Studies Association. 24-26 May 2010. Pecs, Hungary.

Saarinen, J. (2007) 'Protected Areas and Regional Development in Northern Peripheries: Nature Protection, Traditional Economies and Tourism in the Urho Kekkonen National Park, Finland', in Mose, I. (Ed.), Protected Areas and Regional Development in Europe. Towards a New Model for the 21st Century, Ashgate Publishing, Hampshire, England, pp. 199-211.

Sepp, E. (2011) 'Viimaste aastate suundumused Eesti piirkondlikus arengus.' [Recent trends in Estonian regional development], in Eesti Piirkondlik areng 2011, Tallinn, Eesti Statistika, pp. 9-39. 
Endangered Settlements and Protected Areas in Estonia - The Challenge of Maintaining Cultural Landscapes

Smurr, R.W. (2008) 'Lahemaa: the paradox of the USSR's first national park', Nationalities Papers, Vol. 36 No. 3, pp. 399-423.

Stöhr, W.B. (Ed.), (1990) 'Global Challenge and Local Response. Initiative for Economic Regeneration in Contemporary Europe.

Tomson, P. (2007) Ajaloolise maakasutuse mõju Karula rahvuspargi maastike, koosluste ja kaitsekorra kujunemisele. [The impacts of historical land use on formation of landscapes and biotypes and development of the protection regime in Karula National Park.] Unpublished MSc thesis, Estonian University of Life Sciences, Tartu, Estonia. http://www.keskkonnaamet.ee/public/Karula_rahvuspargi_kodulehe_materjalid/MAGIS TRITOO.pdf (Accessed 23 April 2014).

Vollmer, E. (2007) Maade aadeldumine Lahemaa Rahvuspargis [Gentrification in Lahemaa National Park]. Unpublished MSc thesis, Estonian University of Agricultural Sciences, Tartu, Estonia. 


\section{Figures}

Figure 1. Cultural landscape in Sagadi limited management zone in Lahemaa National Park is characteristic of Northern Estonia - open and well-maintained. Photograph by Järv, H. (2014)

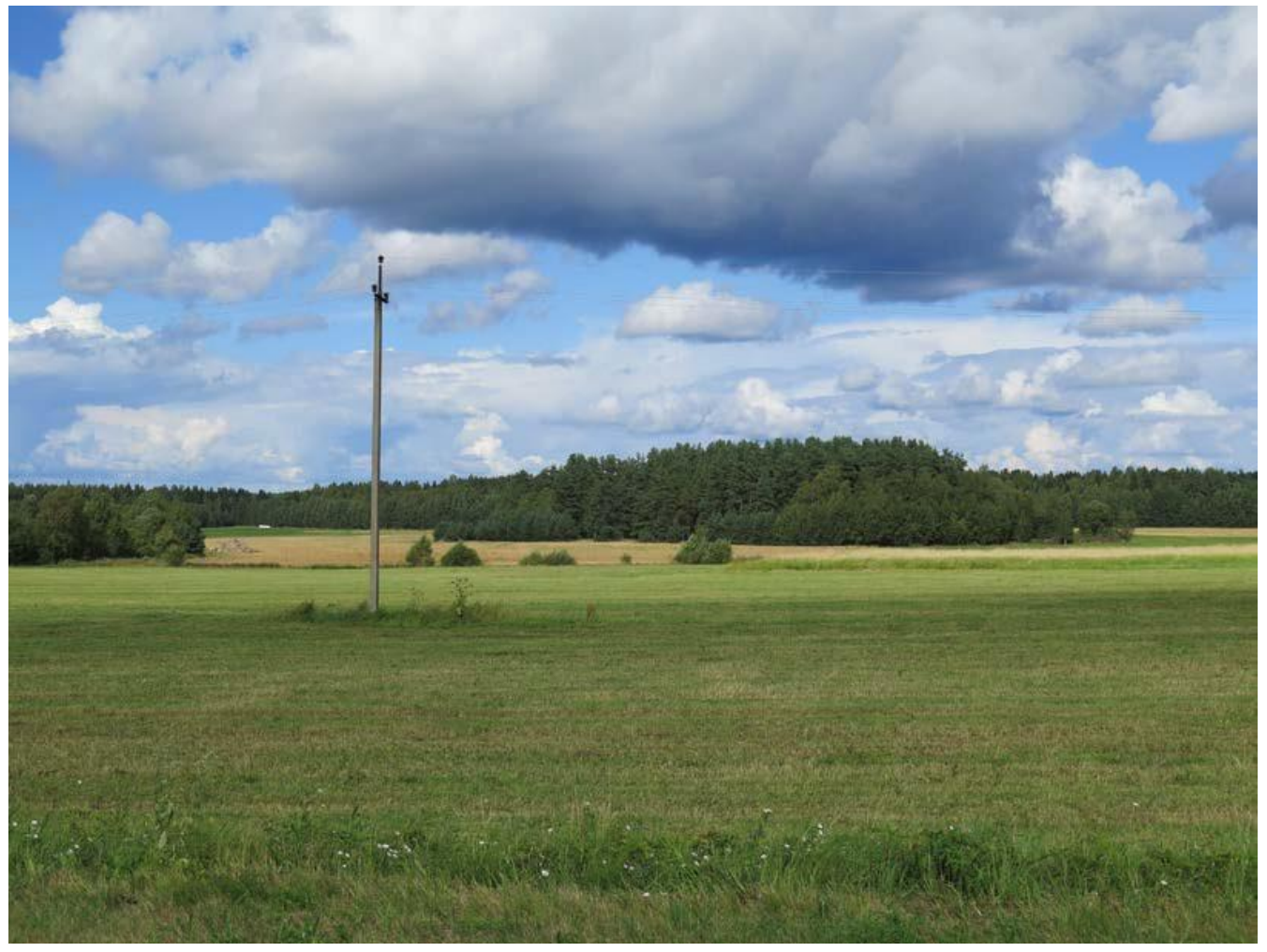


Endangered Settlements and Protected Areas in Estonia - The Challenge of Maintaining Cultural Landscapes

Figure 2. Location of the protected areas of Estonia and problematic settlements within the four studied protected areas

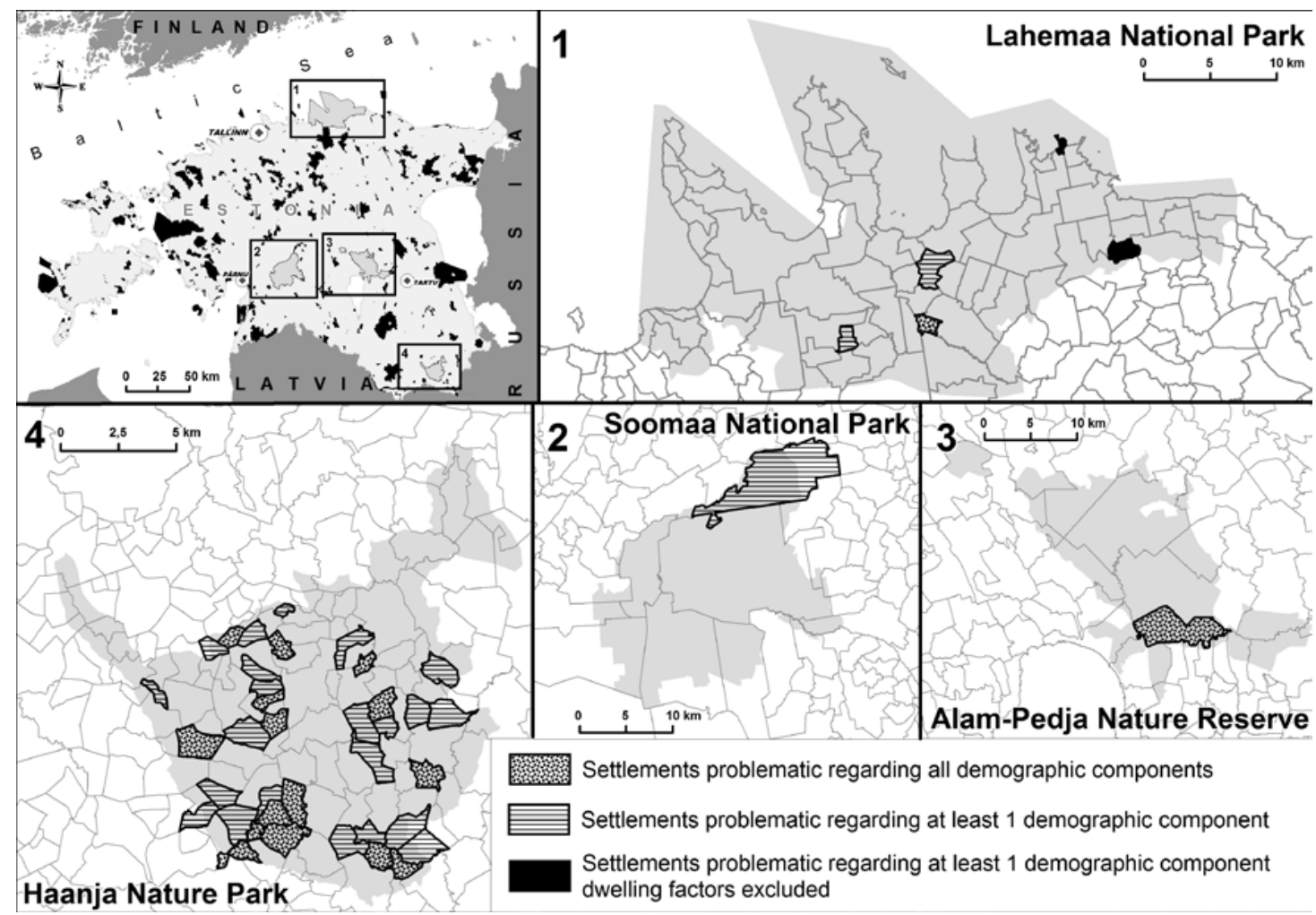


Figure 3. Unmanaged forest due to the protection regime in the Palmse park forest limited management zone of the LNP. In the foreground, there is a naturally fallen tree. Locals call these "taiga traps". Photograph by Järv, H. (2014)

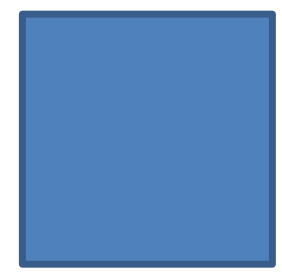

Figure 4. What the residents of the LNP value most about their national park is the "forest milieu", meaning "beautiful" i.e., non-intensively managed forest. The photo shows a recently 'cleaned' spruce forest in the Palmse park forest limited management zone. Photograph by Järv, H. (2014)

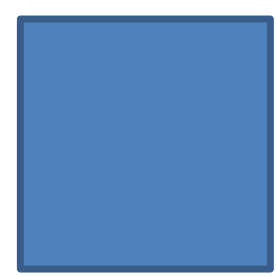

Figure 5. Overgrowth of landscape disturbs the local residents and undermines the image of Lahemaa both in the eyes of the locals and tourists. The photo on the left shows a pasture grazed at the moment; the photo on the right shows a pasture that has not been grazed for some years, on the border of the LNP near Sagadi. Photograph by Järv, H. (2014)

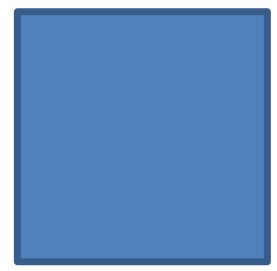


Endangered Settlements and Protected Areas in Estonia - The Challenge of Maintaining Cultural Landscapes

\section{Tables}

Table 1. Demographic indicators of rural settlements in Estonia (as of 2011)

\begin{tabular}{|l|c|c|c|c|}
\hline & \multicolumn{2}{|c|}{ Number of settlements } & \multicolumn{2}{c|}{$\begin{array}{c}\text { Proportion in total number } \\
\text { of settlements, \% }\end{array}$} \\
\hline $\begin{array}{l}\text { Settlements with } \\
\text { less than 5 } \\
\text { inhabitants }\end{array}$ & 389 & $\begin{array}{c}\text { Settlements } \\
\text { in protected } \\
\text { areas }\end{array}$ & Estonia, total & $\begin{array}{c}\text { Settlements } \\
\text { in protected } \\
\text { areas }\end{array}$ \\
\hline $\begin{array}{l}\text { Settlements with } \\
\text { average annual } \\
\text { change in } \\
\text { population in period } \\
\text { 2000-2011 below } \\
-2 \%\end{array}$ & 1749 & 105 & 8.4 & 14.9 \\
\hline $\begin{array}{l}\text { Settlements with at } \\
\text { least 50\% of } \\
\text { residents aged 65 } \\
\text { and older }\end{array}$ & 428 & 39 & 37.8 & 39.0 \\
\hline $\begin{array}{l}\text { Settlements with } \\
\text { less than 5 living } \\
\text { rooms s built in } \\
\text { period 2001-2011 }\end{array}$ & 4041 & 237 & 87.4 & 14.5 \\
\hline $\begin{array}{l}\text { Settlements with } \\
\text { less than 10 living } \\
\text { rooms }\end{array}$ & 1124 & 93 & 24.3 & 34.1 \\
\hline Total settlements & 4621 & 269 & 100.0 & 100.0 \\
\hline
\end{tabular}

Source: Census 2011 (www.stat.ee) 
Table 2. Endangered rural settlements in Estonia

\begin{tabular}{|c|c|c|c|c|}
\hline & \multicolumn{2}{|c|}{ Number of settlements } & \multicolumn{2}{|c|}{$\begin{array}{c}\text { Proportion in total number of } \\
\text { settlements, \% }\end{array}$} \\
\hline & Estonia, total & $\begin{array}{c}\text { Settlements } \\
\text { in protected } \\
\text { areas }\end{array}$ & Estonia, total & $\begin{array}{c}\text { Settlements in } \\
\text { protected } \\
\text { areas }\end{array}$ \\
\hline $\begin{array}{l}\text { Number of } \\
\text { settlements } \\
\text { problematic } \\
\text { regarding all } \\
\text { demographic } \\
\text { components }\end{array}$ & 207 & 20 & 4.5 & 7.4 \\
\hline $\begin{array}{l}\text { Number of } \\
\text { settlements } \\
\text { problematic } \\
\text { regarding at least } 1 \\
\text { demographic } \\
\text { component }\end{array}$ & 515 & 48 & 11.1 & 17.8 \\
\hline $\begin{array}{l}\text { Number of } \\
\text { settlements } \\
\text { problematic } \\
\text { regarding at least } 1 \\
\text { demographic } \\
\text { component; } \\
\text { excluding those } \\
\text { with at least } 10 \\
\text { living rooms or } \\
\text { those where at least } \\
5 \text { living rooms were } \\
\text { built in period } \\
2000-2011\end{array}$ & 487 & 46 & 10.5 & 17.1 \\
\hline Total & 4621 & 269 & 100.0 & 100.0 \\
\hline
\end{tabular}


Endangered Settlements and Protected Areas in Estonia - The Challenge of Maintaining Cultural Landscapes

Table 3. Settlements problematic regarding all demographic components. (2.) Settlements problematic regarding at least 1 demographic component. (3.) Settlements problematic regarding at least 1 demographic component and with at least 10 living rooms 
Jaak Kliimask, Priit-Kalev Parts, Henri Järv, Kalev Sepp, Raymond Ward

\begin{tabular}{|c|c|c|c|}
\hline $\begin{array}{l}\text { Settlement } \\
\text { category }\end{array}$ & Protected area & Settlement & Parish \\
\hline 1. & Alam-Pedja Nature Reserve & Palupõhja & Puhja \\
\hline 1. & Haanja Nature Park & Muna & Rõuge \\
\hline 1. & Haanja Nature Park & Kotka & Haanja \\
\hline 1. & Haanja Nature Park & Vorstimäe & Haanja \\
\hline 1. & Haanja Nature Park & Murdõmäe & Rõuge \\
\hline 1. & Haanja Nature Park & Andsumäe & Haanja \\
\hline 1. & Haanja Nature Park & Saluora & Haanja \\
\hline 1. & Haanja Nature Park & Kahru & Rõuge \\
\hline 1. & Haanja Nature Park & Vastsekivi & Haanja \\
\hline 1. & Haanja Nature Park & Saagri & Haanja \\
\hline 1. & Haanja Nature Park & Peedo & Haanja \\
\hline 1. & Haanja Nature Park & Kaluka & Rõuge \\
\hline 1. & Haanja Nature Park & Mahtja & Haanja \\
\hline 1. & Haanja Nature Park & Palanumäe & Haanja \\
\hline 1. & Haanja Nature Park & Ala-Suhka & Haanja \\
\hline 1. & Haanja Nature Park & Mõõlu & Rõuge \\
\hline 1. & Haanja Nature Park & Vaarkali & Haanja \\
\hline 1. & Haanja Nature Park & Aabra & Rõuge \\
\hline 1. & Lahemaa National Park & Kolgu & Kuusalu \\
\hline 1. & Lahemaa National Park & Aasumetsa & Vihula \\
\hline 2. & Haanja Nature Park & Haki & Rõuge \\
\hline 2. & Haanja Nature Park & Kuuda & Rõuge \\
\hline 2. & Haanja Nature Park & Hapsu & Rõuge \\
\hline 2. & Haanja Nature Park & Haavistu & Haanja \\
\hline 2. & Haanja Nature Park & Käpa & Vastseliina \\
\hline 2. & Haanja Nature Park & Hotõmäe & Rõuge \\
\hline 2. & Haanja Nature Park & Vakari & Haanja \\
\hline 2. & Haanja Nature Park & Kähri & Rõuge \\
\hline 2. & Haanja Nature Park & Jugu & Rõuge \\
\hline 2. & Haanja Nature Park & Udsali & Rõuge \\
\hline 2. & Haanja Nature Park & Pausakunnu & Haanja \\
\hline 2. & Haanja Nature Park & Tiidu & Rõuge \\
\hline 2. & Haanja Nature Park & 6463 Puspuri & Haanja \\
\hline 2. & Haanja Nature Park & Tuuka & Haanja \\
\hline 2. & Haanja Nature Park & Ortumäe & Rõuge \\
\hline 2. & Haanja Nature Park & Kirbu & Haanja \\
\hline 2. & Haanja Nature Park & Kurgjärve & Rõuge \\
\hline 2. & Haanja Nature Park & Kokõ & Rõuge \\
\hline 2. & Haanja Nature Park & Vaalimäe & Haanja \\
\hline 2. & Haanja Nature Park & Leoski & Haanja \\
\hline 2. & Haanja Nature Park & Resto & Haanja \\
\hline 2. & Haanja Nature Park & Purka & Haanja \\
\hline 2. & Haanja Nature Park & Holdi & Haanja \\
\hline
\end{tabular}


Endangered Settlements and Protected Areas in Estonia - The Challenge of Maintaining Cultural Landscapes

\begin{tabular}{|llll|}
\hline 2. & Lahemaa National Park & Tõugu & Vihula \\
2. & Lahemaa National Park & Murksi & Kuusalu \\
2. & Soomaa National Park & Karjasoo & Suure-Jaani \\
\hline 3. & Lahemaa National Park & Natturi & Vihula \\
3. & Lahemaa National Park & Lauli & Vihula \\
\hline
\end{tabular}


Jaak Kliimask, Priit-Kalev Parts, Henri Järv, Kalev Sepp, Raymond Ward

\section{Notes}

\footnotetext{
${ }^{1}$ By post-productivistic countryside we mean a reality where agricultural production in many rural areas has been reduced to a marginal source of income and employment (Evans et al., 2002; Phillips, 2005).

${ }^{2}$ Conservation zones and reserves are secondary for the present analysis as there is generally no economic activity there - there are only few cases when the protection regime of protected areas prescribes grassland maintenance in limited management zones.

${ }^{3}$ The factors in question have been outlined in more detail in Kliimask et al., 2014; only a short summary is presented here.

${ }^{4}$ We use the definition of a $30 \mathrm{~km}$ commuting zone, derived from research by Novak et al., 2013.

${ }^{5}$ There has also been previous research about connections between national parks and settlements that indicates the possibility that protective prescriptions change the value of registered immovables both regarding their agricultural and forest management function and create a precondition for their price increase, both as summer holiday areas and new residential regions. This, in turn, might bring about changes in the social structure of the population (Vollmer, 2006). Nevertheless, this refers to the fact that protection management measures may have indirect effects on the community's ability to cope, its structure and settlement behaviour, even if the measures concern areas that have never found significant use for economic purposes.
} 